\title{
PROBLEMATIKA PEMBELAJARAN KETERAMPILAN BERBICARA BAHASA ARAB BERBASIS KOMUNIKATIF INTERAKTIF DALAM BINGKAI PEMBELAJARAN KITAB KUNING
}

\author{
Ahmad Helwani Syafi'i' ${ }^{1}$, Nurjanah ${ }^{2,}$, Husnan ${ }^{3}$ \\ 1,2,3Program Studi PBA, Universitas Muhammadiyah Mataram, Indonesia \\ ahelwani1407@gmail.com ${ }^{1} \underline{\text { arkounfukayna@gmail.com }^{2}} \underline{\text { husnanhanan4780@gmail.com }^{3}}$
}

\section{INFO ARTIKEL}

\section{Riwayat Artikel:}

Diterima: 02-03-2021

Disetujui: 30-04 -2021

\section{Kata Kunci: \\ Keterampilan \\ berbicara bahasa \\ Arab, \\ Komunikatif \\ interaktif, \\ Kotab kuning.}

\begin{abstract}
ABSTRAK
Abstrak: Problematika yang sering ditemukan oleh guru dalam proses pembelajaran bahasa arab adalah problem liguistik yang kendala dalam menemukan ide-ide pokok dalam konteks pembelajaran sehingga siswa kesulitan dalam berbicara untuk menjelaskan untuk atau memberikan argument terkait materi yang disampaikan oleh guru. Hal ini berakibat pada multi tafsir dan pesan-pesan pembelajaran menjadi sulit untuk dipahami oleh siswa. Penelitian ini bertujuan: Untuk mengetahui problematika dan solusi apa yang dilakukan dalam meningkatkan kemampuan keterampilan berbicara bahasa Arab. Penelitian ini menggunakan pendekatan kualitatif, dengan tujuan untuk memahami fenomena tentang apa yang dialami subyek penelitian. Tehnik pengumpulan data menggunakan tehnik observasi, wawancara, dokumentasi. Analisis data menggunakan model Miles dan Hubberman: reduksi data, penyajian data dan verifikasi. Hasil penelitian: Problematika dan solusi yang dilakukan dalam peningkatan kemampuan berbicara berbasis komunikatif intraktif dalam bingkai pembelajaran kitab kuning terdiri dari beberapa faktor yaitu: bakat, minat, motivasi dan kemampuan awal siswa yang termasuk pada faktor internal. Sedangkan faktor eksternalnya terdiri dari guru, kurikulum dan milieu.
\end{abstract}

\begin{abstract}
Problems that are often found by teachers in the process of learning Arabic language is liguistic problems that constraints in finding the main ideas in the context of learning so that students have difficulty in speaking to explain to or give arguments related to the material delivered by the teacher. $T$ his results in multi-interpretation and learning messages becoming difficult for students to understand. This study aims: To find out the problem and what solutions are done in improving the ability of Arabic speaking skills. This study uses a qualitative approach, with the aim of understanding the phenomenon of what the study subjects experienced. Data collection techniques using observation techniques, interviews, documentation. Data analysis using the Miles and Hubberman models: (1) data reduction (2) data presentation and verification. The results of the study: Problems and solutions conducted in improving the ability to speak communicatively intractive in the frame of learning the yellow book consists of several factors, namely: talents, interests, motivations and early abilities of students included in internal factors. While the external factors consist of teachers, curriculum or materials and milieu.
\end{abstract}

\section{A. LATAR BELAKANG}

Pendidikan merupakan langkah kongkrit pemerintah dalam meningkatkan kualitas sumber daya manusia dalam menempuh dunia global sekarang ini yang makin menantang, baik dari segi spritual, sosial dan emosional. Dengan demikian pendidikan merupakan salah satu alternatif dalam memecahkan permasalahan bangsa yang saat ini makin merosot, sebagaimana yang diamanatkan dalam UUD SISDIKNAS dalam pasal 1 yang menjelaskan bahwa: Pendidikan adalah usaha sadar dan terencana untuk mewujudkan suasana belajar dan proses pe mebelajaran agar peserta didik secara aktif mengembangkan potensi dirinya untuk memiliki kekuatan spritual keagamaan, 
pengemndalian diri, kepribaian, kecerdasan, akhlak mulia, serta keterampilan yang diperlukan dirinya, masyarakat, bangsa dan negara.

Rumusan undang-undang di atas menjadi acuan dasar dalam mengembangkan kompetensi siswa dalam semua sisi terutama yang berkaitan dengan keterampilan, yang dalam hal ini keterampilan berbicara. Keterampilan berbicara dianggap sebagai tolok ukur kemampuan siswa dalam berkomunikasi dan dalam menentukan kemampuan siswa dalam berpikir kritis dan mendalam. Kemampuan berbicara khususnya dalam pembelajaran bahasa arab menjadi prasyarat penting demi menunjang kegiatan belajar mengajar dan merupakan point penting yang harus diajarkan oleh guru kepada siswa untuk mengusai keterampilan berbicara dan harus dikuasainya baik secara teori maupun praktik tertuama dalam berkomunikasi baik antar sesama (siswa) maupun kepada guru.

Guru dalam proses pembelajaran bahasa (baca: bahasa arab) biasanya mengembangkan keterampilan siswa yang notabene-nya mengarah pada keterampilan secara vertikal yaitu keterampilan yang mengarah pada pembentukan pola pikir dalam mengungkapkan pesan-pesan secara lengkap meskipun belum sempurna, dan melalui proses pembelajran yang intent dan runut maka pesan-pesan yang diperoleh akan semakin baik dan sempurna. Mengutip pendapatnya Darmayati Zuhdin (2000: 7) menjelaskan ada tiga cara untuk mengembangkan keterampilan siswa secara vertikal yaitu: a) menirukan pembeiaraaan orang lain (khususnya guru); b) mengembangkan bentuk bentuk ujaran yang dikuasai; c) mendekatkan/ mensejajarkan dua bentuk ujaran yaitu ujaran sendiri yang belum benar dengan ujaran orang dewasa (terutama guru) yang sudah benar.

Berdasarkan hasil observasi awal yang peneliti lakukan di Pondok Khusus Al-Halimy, ditemukan bahwa, rata-rata siswa/santri mengalami hambantan dalam menyampaikan pesan dari kontent/isi pelajaran. Ketika santri diminta untuk mendeskripskan, menganalisis hambatan yang sering terjadi adalah ketidakmampuan siswa/santri dalam berbicara sesuai dengan kaidah bahasa arab, sehingga pengalaman belajar yang diperoleh menjadi terhambat dan terkesan biasa saja.

Selain itu, problem yang ditemukan adalah kurangnya waktu untuk mengulang materi-materi yang terdapat pada kitab kuning yang dipelajari sehingga pembelajaran seakan tersendat dan sering di ulang-ulang. Kemudian siswa/santri sering enggan untuk tampil di depan untuk menjelaskan materi yang dipelajari dan tidak terlalu serius dalam menyampaikan materi pembelajaran.

penelitian ini bertujuan untuk : mengetahui problematika dan solusi apa yang dilakukan dalam meningkatkan kemampuan keterampilan berbicara bahasa Arab.

\section{B. METODE PENELITIAN}

Dalam upaya memperoleh data yang akurat terkait tentang keterampilan berbicara berbasis komunikatif, maka penelitian ini menggunakan pendekatan kualitatif, dimana penelitian ini dilakukan dalam situasi yang alamiah, wajar dan latar yang sesungguhnya (natural setting). Adapun karakteristik penelitian kualitatif menurut Robert C. Bogdan dan Sari Knopp Biklen (2017:4-7) menjelaskan yaitu: Qualitative research has actual settings at the direct source of data and the researcher is the key instrument, descriptivedata. qualitative reseach is descriptive. The data collected take the form of word or pictures rather than numbers, concern with process. Qualitative researcher are concernet with process rather than simply with outcomes or products, inductive. Qualitative researcher tend to analize their data inductively, meaning."meaning"is of essential concern to the qualitative approach, and Reseacher who use this approach are interested in how differnet people makesense of their lives.

Jenis penelitian yang digunakan dalam penelitian ini adalah jenis penelitian kualitatif. Dalam metode kualitatif ini penelitian dilakukan dengan penelitian lapangan. Penelitian lapangan merupakan studi mendalam mengenai unit social tertentu, yang hasil penelitian ini memberikan gambaran luas dan mendalam mengenai unit sosial tertentu.

Moleong $(2012,6)$ memaparkan bahwa, penelitian kualitatif adalah penelitian yang bermaksud untuk memahami fenomena tentang apa yang dialami subyek penelitian misalnya perilaku, persepsi, motivasi, tindakan, dll., secara holistik dan dengan cara deskripsi dalam bentuk kata-kata dan bahasa, pada suatu konteks khusus yang alamiah dan dengan memanfaatkan berbagai metode alamiah. 
Sehubungan dengan dengan pelaksanaan penelitian ini, penulis melakukan pendekatan dengan pendekatan kualitatif karena data yang akan diperoleh di lapangan lebih banyak berupa informasi, konsep-konsep dan keterangan-keterrangan bukan dalam bentuk angka-angka. Yang dalam hal ini peneliti akan meneliti tentang kegiatan siswa/ santri terkait peningkatan kemampuan berbicara brbahasa arab secara komunikatif di Pondook Khusus AlHalimy sesela Lombok Barat.

Setelah instrumrn tersusun, maka langkah selanjutnya di uji validitas. Jhon W. Creswell (2014:3 47) mendefinisikan bahwa"validasi" dalam penelitian kualitativ sebagai usaha untuk menilai "akurasi" dari berbagai temuan, sebagai mana yang di deskripsikan dengan baik oleh peneliti dan para partisipan. Dalam pnelitian ini, validitas instrumen yang di lakukan melaui validitas isi (content validiti), apakah instrument berisi materi yang benar? apakah butir butir tes konsisten dengan konten pelajaran? Apakah perilaku berhubungan dengan diagnosis kmampuan? Apakah penilaian mewakili tingkat kriteria? (Tayib Napis, Farida Yusuf, 2018:107). Selain itu, uji validitas internal dilakukan dengan konsultasi dan diskusi ahli.

Dalam penelitian ini pengumpuln data dilakukan pada natural setting (kondisi alamih), sehingga teknik pengumpulan data lebih banyak pada observasi, wawancara, dokumentasi dan quisioner. Chaterine Marshall, Gretchen B. Rossman dalam Sugiyono (2014:377) menyatakan bahwa "the fundamental methodes relied onby qualitative researchers for gathering information are, participation in the setting, direct, observation in-depth interviewing, document review".

Selain itu, Norman K. Denzin dan Yvonna S. Lincoln (2019:707) mengungkapkan bahwa stiap pendekatan kualitatif untuk melakukan evaluasi program memiliki freferensi metode kualitativ sendiri sendiri, yang meliputi: intervew opended, observasi on-site, observasi partisipan, dan ulasan dokumen. Dalam menentukan informan maka peneliti menggunakan teknik purposive sampling, maka peneliti menetapkan informan kunci pada penelitian dalam pelaksana adalah kepala sekolah, wakil kepala sekolah, guru, orang tua murid, peserta didik dan orang tua.

Analsis data dalam penelitian ini menggunakan medel yang dekembangkan oleh Matthew B. Miles dan A. Micheal Huberman (2014:118), dimana mtode analisis data kualitatif melalui tiga aktivitas, yaitu (1) reduksi data (data reduction), (2) penyajian data (data display) dan (3) penarikan kesimpulan dan verifikasi (conclusion drawing/verification).

Mereduksi data brarti merangkum (Mappanyompa \& Mustapa Ali, 2017), memilih hal-hal yang pokok,memfokuskan pada hal-hal yang penting,dicari tema dan polanya. Dengan demikian data yang telah dirduksi akan membrikan gambaran yang lebih jelas, dan mempemudah peneliti untuk melakukan pengumpulan data selanjutnya, dan mencarinya bila perlukan. Dalam penelitina kualititaf, penyajian ata bisa dilakukan dalam bentuk uraian singkat, bagan, hubungan antar katagori, plowchart, dan sejenisnya.

Langkah ketiga dalam analisis data kualitatif adalah penarikan kesimpulan dan verifikasi merupakan temuan baru yang sebelumnya belum pernah ada. Temuan dapat berupa deskripsi atau gambaran suatu obyek yang sebelumnya masih samar-samar atau gelap sehingga setelah diteliti menjadi jelas, dapat berupa hubungan kausal atau interaktif, hipotesis atau teori

\section{PEMBAHASAN}

\section{1. problematika santri dalam berbicara bahasa Arab berbasis komunikatif intraktif}

Problematika atau hambata selalu menjadi salah aspek yang menyelimuti setiap kegiatan yang dilakukan apalagi itu terkait dengan dunia pendidikan. Pendidikan dan pembelajaran dilihat dari hari ke hari di samping melakukan pembenahan dan kemajuan di beberap aspek tetapi tidak luput dari masalah yang selalu timbul. Masalah yang dihadapi tidak terlepas dari beberapa komponen pendidikan seperti: kurikulum yang sudah usang dan sesuai lagi degan perkembangan zaman, materi yang disampaikan terlalu pada sehingga sulit dipahami siswa dan banyak lagi permasalahan yang lain. 
Belum lagi ketika menyangkut masalah pendanaan yang selalu saja menajdi barometer proses pendidikan untuk semua lembaga pandidikan baik pemerintah maupun swasta. Lembaga pendidikan swasta yang dalam hal ini pondok pesantren dengan corak pendidikannya yang masih konservatif-religius mengedepankan pendidikan yang lebih mengarah pada kajiankajian kitab kuning yang membutuhkan keterampilan yang lebih dibanding dengan sekolah umum pada umumnya, sehingga permasalah yang muncul bisa terbilang rumit. Misalnya, dilihat dari aspek santri yang masih asing dengan kajian kitab kuning, kerap kali merasa terbebani dengan berbagai kaidah yang ada didalamnya, muatan materi yang cukup sulit dipahami.

Disamping itu diharuskan untuk semua santri untuk mampu berbahasa Arab agar mampu membaca, menerjemahkan, menulis dan memecahkan permasalahan yang terdapat di dalam materi. Untuk lebih memudahkan kajian ini, penulis membaginya secara umum permasalahan yang di hadapi khususnya di pondok khusus alhalimy menjadi dua faktor yaitu faktor internal dan faktor eksternal, sebagaimana yang akan dijelaskan di bawah ini:

a. Faktor internal

Faktor internal bisa dimaksudkan sebagai faktor yang berasal dari santri pondok khusus alhalimy yang belajar keterampilan berbicara bahasa Arab. Santri merupakan obyek dari pendidikan untuk menyiapkan generasi yang akan baik dari segi spritualitas, sosial dan moralnya. Faktor ini merupakan yang yang paling penting karena semua sasaran pendidikan akan mengarah pada peningkatan kemampuan santri baik secara kualitatif maupun kuantitatif. Oleh karena itu perlu kiranya untuk menbedakan beberapa hal yang menjadi permasalahan yang sering muncul pada santri dalam proses pembelajaran keterampilan berbicara bahasa Arab yaitu:

\section{1) Bakat}

Setiap santri memiliki keunikan tersendiri yang menjadi pembeda dengan santri yang lain. Kadangkala sering luput dari perhatian para guru yang mengajar karena tidak memperhatikan karakteristik santri terutama dilihat dari bakat yang dimilkinya. Biasanya guru dalam proses pembelajaran akan menseragamkan materi dan metode dalam mengajar sehingga aspek bakat yang dimiliki santri tidak terjamah.

Bakat biasanya diartikan sebagai kemampuan bawaan yang merupakan potensi (potential ability) yang masih dikembangkan atau dilatih agar dapat terwujud. Bakat merupakan kemampuan alamiah untuk memperoleh pengetahuan atau keterampilan, yang relatif bersifat umum (misalnya, bakat intelektual umum) atau khususnya (bakat akademis khusus) (Sabur, 2003: 181).

Penjelasan diatas mengarahkan guru untuk melihat secara jeli bakat yang dimilki siswa, karena bakat bawaan sangat mempengaruhi kegiatan belajar siswa di dalam proses pembelajaran. Seperti halnya yang terjadi di pondok khusus alhalimy, banyak santri-santri yang memiliki bakat dalam mempelajari kitab kuning tetapi permasalahan yang muncul adalah kurang cakapnya mereka dalam memahami materi karena keterbatasan bahasa yaitu bahasa Arab.

Sehingga perlu kiranya untuk mengetahui bakat santri agar memudahkan guru untuk mengajar. Cara yang bisa ditempuh misalnya dengan menggunakan pendekatan individu. Labihlebih jika guru menemukan santri yang pendiam, pemalu dan sangat tertetup yang merupakan hambatan terbesar dalam proses komunikasi karena tidak memahami karakter siswa terutama bakat yang terpendam dalam diri santri.

\section{2) Minat}

Hal yang selanjutnya yang harus diperhatikan adalah terkait dengan minat siswa dalam belajar. Walapun guru sudah menyiapkan materi dengan sangat baik dan pemilihan metode dan media yang baik pula jika minat belajar siswa tidak ada maka sedikit sekali peluang guru untuk bisa mencapai tujuan yang telah ditetapkan.

Minat bisa dikatagorikan sebagai faktor yang sangat penting untuk diperhatikan oleh guru. Karena minat juga menunjang siswa dalam mengoptimalkan kemampuannya dalam belajar. Dari hasil analisis penulis, para santri di pondok khusus al-halimy bisa dimaksimalkan belajarnya jika para guru mampu mengembangkan minat para santri. Karena rat-rata santri yang masuk di pondok khusus al-halimy secara akademis memang berminat dalam mengaji tentang kitabkitab klasik. Tapi dalam praktiknya, hambatan yang selalu muncul adalah setiap santri memilki minat yang berbeda-beda, ada yang contoh mempelajari kaidah-kaidah bahasa Arab tetapi dalam praktiknya santri seperti kewalahan, semacam ada gap sehingga perlu peninjauan ulang.

Ketika santri memiliki minat terhadap suatu pelajaran tertentu maka mereka akan fokus untuk mendalami materi dan atau kitab yang sedang dipelajari. Tetapi lagi-lagi yang jadi permasalahan adalah kejelian guru dalam melihat minat yang dimiliki santri. Sebagaimana yang dijelaskan slameto (2015: 57) minat adalah kecendrungan 
yang tetap untuk memperhatikan dan mengenang beberapa kegiatan. Kegiatan yang diminati seseorang, diperhatikan terus menerus yang disertai rasa senang tanpa adanya batasan waktu.

\section{3) Kemampuan awal santri}

Pengetahuan awal santri merupakan dasar bagi guru dalam menyusun materi yang akan disampaikan dalam proses pembelajaran kitab kuning. Tapi pada kenyataannya adalah permasalahan yang sering muncul adalah kebanyakan santri yang berasal dari sekolah umum yang masih perlu beradaptasi untuk bisa mengikuti pelajaran kitab kuning yang diajarkan oleh guru. Di sisi lain, keterbatasan santri dilihat dari aspek penguasaan kosa kata yang terbilang masih kurang. Disamping penguasaan kaidahkaidah bahasa Arab yang notabene-nya terbilang sangat sulit bagi santri yang baru belajar kitab kuning.

Sedangkan jika dilihat dari faktor guru, maka kesulitan yang sering dialami oleh guru adalah kurangnya guru dalam memahami kemampuan awal siswa baik dari segi kapasitas dan modalitas belajar santri. Implikasi dari kemampuan awal santri dalam belajar adalah tingkat kesiapan santri dalam menerima materi yang disampaikan guru, sehingga banyak santri yang menerka-nerka maksud yang ingin disampaikan dalam proses pembelajaran.

\section{4) Kemauan dan motivasi belajar}

Secara psikologis motivasi merupakan unsur yang paling vital dalam setiap pekerjaan yang dilakukan terutama dalam proses pendidikan. Motivasi bisa dikatakan sebagai prasyarat utama santri dalam belajar apalagi ketika belajar tentang kitab kuning dengan menggunakan bahasa Arab yang memiliki kesulitan-kesulitan yang sangat banyak.

Para pakar pendidikan yang konsen dalam psikologi pendidikan berpendapat bahwa, setiap siswa seharusnya dibekali dengan motivasi di awal proses pembelajaran agar santri hadir secara utuh dalam proses pembelajran (baca: kosentrasinya tidak terpecah dan terbagi-bagi) selain tetap fokus dengan materi yang disampaikan oleh guru.

\section{b. Faktor eksternal}

Faktor eksternal bisa dipahami sebagai sesuatu yang berada di luar yakni segala sesuatu yang mampu mempengaruhi santri dalam belajar sebagaimana yang akan dipaparkan di bawah ini:

1) Guru
Guru merupakan sosok yang berpengaruh dalam mempengaruhi perkembangan siswa belajar. Tugas-tugas yang harus dilakukan adalah menyusun silabus dan RPP, menyusun materi yang akan disampaikan dan pemilihan media dan metode. Dari setiap kegiatan guru tersebut, permasalahan yang sering muncul adalah pengelolaan kelas yang dilakukan bisa dibilang kurang maksimal. Dari hasil pengamatan diketahui bahwa kelas tempat santri belajar bisa dikatakan masih terbuka atau semi outdoor sehingga suarasuara luar bisa masuk dan berpengaruh dalam proses pembelajaran.

Metode dalam pembelajaran yang dilakukan guru dalam rangka peningkatan keterampilan santri berbicara bahasa Arab di sering monoton dan terlalu sering menggunakan metode konvensional (baca: ceramah) sehingga tidak jarang banyak santri yang tidur, ngantuk dan tidak berminat mengikuti proses pembelajaran. Di lain sisi waktu pembelajaran terbilang padat sehingga santri tidak bisa istrirahat yang cukup sehingga merasa berat untuk mengikuti pembelajaran selanjutnya.

\section{2) Kurikulum/materi}

Materi pembelajaran bahasa Arab cenderung terbilang susah dan sulit untuk dipahami oleh santri, apalagi untuk santri pada jenjang yang lebih rendah. Adapun untuk jenjang yang lebih tinggi kesulitan yang sering dialami adalah penerapan kaidah-kaidah bahasa Arab ketika santri membaca, menerjemahkan kitab yang sedang dikaji. Kecenderungan dalam proses pembelajaran guru sering memberikan materi yang cukup padat sehingga santri merasa sangat berat ditambah lagi lingkungan yang tidak kondusif.

\section{3) Milieu (lingkungan)}

Lingkungan disini bisa dikatagorikan dalam dua bentuk yaitu sekolah dan keluarga. Pertama, lingkungan sekolah sangat berpengaruh dalam membentuk karakter siswa. Karena memang sekolah disiapkan untuk mengasah dan mengoptimalkan kapasitas santri dalam menuntut ilmu. Kelamahan yang muncul di sini adalah lembaga pendidikan (baca: sekolah, pondok) tidak menyediakan wadah untuk santri mengembangkan bakat dan minatnya.

Kedua, lingkungan keluarga, merupakan pendidikan pertama yang diterima oleh santri sebelum belajar di pondok atau sekolah. Hambatan yang sering muncul dari aspek ini adalah perbedaan sosiokultural yang menjadi penghalang santri dalam belajar. Perbedaan sosikultural yang mengiktari santri sehingga sering terjadi 
miskomunikasi antara santri dengan guru dan santri dengan santri.

\section{Solusi yang dilakukan dalam mengatasi hambatan berbicara berbasis komunikatif intraktif}

Setiap proses yang dilakukan memiliki hambatan yang harus dihadapai tetapi juga memilki upaya untuk mengatasinya dalam bentuk solusi-solusi praktis-pragmatis agar tujuan pendidikan dan pengajaran yang ingin dicapai bisa maksimal. Adapun penjelasannya adalah sebagai berikut:

\section{a. Faktor internal}

Faktor ini berbicara tentang siswa/santri secara khusus karena santri sebagai obyek dari proses pendidikan, maka sudah sewajarnya semua kapasitas santri baik dari bakat, minat, motivasi/kemauan dan kemampuan awal siswa harus dimaksimalkan dengan sempurna. Karena tujuan utama dalam proses pendidikan mampu merubah santri ke arah yang lebih dan peningkatan skill yang dimiliki baik secara hardskiil dan softskiil-nya. Jika kemampuan siswa tidak tercapai dengan sempurna maka bisa dikatakan tujuan pendidikan yang digalakan gagal.

Selain itu ada upaya strategis dari semua civitas akademik untuk meningkatkan standar mutu pendidikan agar siswa tidak merasa menjadi korban guru, kepala sekolah dan tendik lengah karena kurang peka dengan keinginan dan kemauan siswa ketika proses pembelajran berlangsung atau ketika siswa berada di luar kelas.

Lembaga juga harus mampu membuat tujuan-tujuan jangka pendek yang harus dikusai oleh siswa dalam belajar, agar mudah membuat barometer tingkat ketercapain siswa, dan keterlambatan siswa. Disamping membuat sebuat wadah untuk pengembangan bakat-bakat yang dimilki oleh siswa yang masih terpendam agar bisa disalurkan secara akademik.

\section{b. Faktor eksternal}

Adapun faktor ekternal atau sesuatu yang berpengaruh dalam pendidikan siswa yang berada di luar mereka seperti guru, kurikulum dan juga lingkungan siswa. Dilihat dari sisi guru, masalah yang dihadapai oleh guru diantisipasi dengan mencari waktu yang sedikit sepi dan tenang untuk memulai proses pembelajran agar kosentrasi siswa tidak terpecah. Kemuadian guru seyogyanya menggunakan metode yang bervariasi karena setiap materi bisa diajarkan dengan metode yang seragam alih-alih metode ceramah.
Sedangkan dilihat dari materi ajarnya, karena pembelajran kitab kuning membutuhkan keterampilan berbicara bahasa Arab yang menjadi prasyarat maka guru harus mampu mengurasi muatan konten yang dipelajari. Karena kepadatan materi ajar akan membuat pemahaman siswa menjadi parsial tidak menyeluruh. Karena ketika siswa sedang memahami pelajaran yang baru dijelaskan guru sudah pindah atau melanjutkan materi selanjutnya, atau bisa ditanggulangi dengan mencari jam lebih untuk meminimalir keterlambatan siswa dalam belajar.

Terakhir adalah terkait masalah lingkungan sekolah dan lingkungan keluarga. Sekolah perlu menyediakan siswa wadah untuk pengembangan bakat minat yang dimilki siswa, selain itu menambah sarana dan prasana untuk siswa belajar. Sedangkan dari sisi keluarga, guru harus mengetahui kultur siswa yang diajar agar tidak sering terjadi miskomunikasi dalam proses pembelajaran.

\section{SIMPULAN}

Hambatan dan solusi yang dilakukan dalam peningkatan kemampuan berbicara berbasis komunikatif intraktif dalam bingkai pembelajaran kitab kuning

1. Hambatan santri dalam berbicara berbasis komunikatif intraktif terdiri dari beberapa faktor yaitu: bakat, minat, motivasi dan kemampuan awal siswa yang termasuk pada faktor internal. Sedangkan faktor eksternalnya terdiri dari guru, kurikulum atau materi dan milieu (sekolah dan keluarga)

2. Solusisantri dalam berbicara berbasis komunikatif intraktif yaitu pada faktor internalnya yaitu guru dan semua civitas akademik harus mampu memaksimalkan semua kapasitas siswa dalam proses pembelajaran sehingga tujuan bisa dicapai dengan maksimal. Sedangkan pada faktor eksternalnya sekolah menyediakan sarana dan prasana yang mumpuni dan menyediakan wadah dalam pengembangan bakat dan minatnya.

\section{DAFTAR RUJUKAN}

Abdul Wahab Rosyidi, Media Pembelajaran Bahasa Arab, Malang: UIN Malang Press, 2019.

Abu Ahmadi dan Joko Tri Prasetya, Stategi belajar mengajar, Bandung: CV Pustaka Setia, 2015

Acep Hermawan, Metodologi Pembelajaran Bahasa Arab, Bandung: PT. Remaja Rosdakarya, 2011 
Alex sobur, Psikologi umum, Bandung: pustaka setia, 2013

Azhar Arsyad, Bahasa Arab dan Metode Pengajarannya, Surabaya: Pustaka Pelajar, 2013

Azhar Arsyad, Media pembelajaran, Jakarta: PT Raja Grafindo Persada, 2018

E.G. Cohen, Designing Groupwork: Strategies For the Heterogeneous Classroom. New York: Teachers Cpllege Press. 2016

Hidayat, Musyikilat Taris Ta'lim Al-Arabiyah Fi Indonesia Wa Ilagiha, AlMuwajah Fi Ta'lim Al-Lughoh Al-Arabiyah, Jakarta:2018

Lazuardi, Yogyakarta: Pustaka Pelajar, 2014.

Matthew B. Milles dan A. Micheal Haberman, Analisis Data Kualitatif terj. Tjeptjep Rohendi Rohidi, Jakarta: Universitas Indonesia, 2014.

M. Ainin dkk, Evaluasi Dalam Pembelajaran Bahasa Arab, Malang: Myskat, 2016.

M. Farid dkk. Pengaruh Model Pembelajaran Problem Solving Berbantuan Multimedia Interaktif terhadap Keterampilan Berbahasa. Jakarta: 2017

Mappanyompa, M. M., \& Mustapa Ali, M. A. M.

A. (2017). Urgensi Penggunaan Multimedia Interaktif Terhadap Peningkatan Motivasi Belajar Siswa Dalam Pembelajaran Bahasa Arab Kelas Va Min Malang 2. Ibtida'iy: Jurnal Prodi PGMI, 2(2), 54. https://doi.org/10.31764/ibtidaiy.v2i2.1049

Slameto, Belajar dan faktor-faktor yang mempengaruhi, Jakarta: PT Rineka Cipta, 2015

Sri Wahyuni, dkk, Bahasa Indonesia 1, Surabaya : Lapis - PGMI , 2018

Taufik Hidayat dkk. Rancangan Strategi Pendidikan Berbahasa Santun dalam Pembelajaran Berbicara. Jakarta: 2019

Teti Nulyati, dkk, Bahasa Indonesia,Jakarta : Universitas Terbuka, 2011

Undang-undang Nomor 20 Tahun 2013 tentang Sistem Pendidikan Nasional

W.M. Rivers, Interaktive Language Teaching. Cambridge, England: Cambridge University Press. 2017

Wina sanjaya, Strategi pembelajaran berorientasi standar proses pendidikan, Jakarta: kencana

Yudhi Munadhi, Media pembelajaran (sebuah pendekatan baru), Jakarta: Gaung Persada, 2012.

Zulela, Pembelajaran Bahasa Indonesia di Sekolah Dasar, Bandung : PT RemajaRosdakarya. 